\title{
Comparison of Molecular Procedures for Detection and Identification of Guignardia citricarpa and G. mangiferae
}

\author{
N. A. Peres, University of Florida, Gulf Coast Research and Education Center, Wimauma 33598; R. Harakava, \\ Instituto Biológico, São Paulo, Brazil; G. C. Carroll, Department of Biology, University of Oregon, Eugene 97403; \\ J. E. Adaskaveg, Department of Plant Pathology, University of California, Riverside 92521; and L. W. Timmer, \\ University of Florida, Citrus Research and Education Center, Department of Plant Pathology, Lake Alfred 33850
}

\begin{abstract}
Peres, N. A., Harakava, R., Carroll, G. C., Adaskaveg, J. E., and Timmer, L. W. 2007. Comparison of molecular procedures for detection and identification of Guignardia citricarpa and $G$. mangiferae. Plant Dis. 91:525-531.

Citrus black spot, caused by Guignardia citricarpa, is a serious fruit spot disease and is widely distributed in Asia, southern Africa, and South America, but does not occur in North America or the Mediterranean region. A nonpathogenic species, G. mangiferae, is cosmopolitan with a wide host range and can colonize citrus fruit and leaves saprophytically. Detection and identification of Guignardia spp. on citrus fruit is necessary for epidemiological, management, and regulatory purposes. In this study, we compared published and unpublished polymerase chain reaction primer sets for their specificity and sensitivity in the detection and differentiation of the two Guignardia spp. All primers evaluated successfully identified the two species using purified DNA from fungal cultures or mycelia as source materials. However, some primer sets were not highly effective in detecting $G$. citricarpa when DNA was extracted directly from single characteristic black spot lesions on fruit. Thus, new primer pairs for both species were designed from the internal transcribed spacer region that were highly sensitive and specific for detection of $G$. citricarpa using DNA recovered from single lesions on fruit by a rapid DNA extraction procedure.
\end{abstract}

Citrus black spot, caused by Guignardia citricarpa Kiely, has become a serious problem for citrus production in Asia and in many areas of the southern hemisphere $(8,17,18,28)$. The pathogen produces airborne ascospores in decomposing leaf litter on the grove floor that form quiescent infections on fruit and leaves (12,13, 17,18,20,22,31). Conidia produced by pycnidia of the anamorph of the fungus, Phyllosticta citricarpa (McAlpine) van der Aa, also may infect fruit and leaves. Symptoms on fruit include hard spot lesions (raised black edges and tan centers that often bear pycnidia), false melanose (small, raised, dark lesions that often coalesce and have been attributed to conidial infection), freckle spots (sunken reddish lesions that may coalesce to form large areas called virulent spot), and cracked spots (raised dark lesions with irregular margins) $(10,14,17,18)$. Infections usually occur early in the season, from petal fall until about midsummer, but symptoms

Corresponding author: N. A. Peres

E-mail: nperes@ufl.edu

This research was supported in part by Project No. 5300-117 of the California Citrus Research Board.

Accepted for publication 8 November 2006.

doi:10.1094/PDIS-91-5-0525

(C) 2007 The American Phytopathological Society usually do not develop until the fruit begin to mature (29). If symptoms develop early, fruit may abscise prematurely, reducing crop yield. Fruit with symptoms are not suitable for fresh market use; however, fruit that are asymptomatic at harvest may still develop symptoms during transport or in the market. Quiescent infections occur on leaves, but leaf spot symptoms are uncommon and occur mostly on highly susceptible species such as lemon.

Black spot has not been reported in the United States or in Mediterranean citrusproducing countries. Regulatory measures restrict market access for countries with black spot and reduce the availability of citrus fruit for consumers in the northern hemisphere (26) but potentially protect against the dissemination of the pathogen to other citrus-producing areas. The European Community accepts fruit from citrus areas with black spot, but fruit must be free of symptoms $(4,23)$. The United States does not currently allow importation of fresh citrus fruit from areas with black spot. Because symptoms may develop during transport, entire loads of fruit may be rejected at the port of entry. Effective fungicide programs during the season may substantially reduce the number of infections in the field and quiescent infections that develop on fruit after harvest (1). Fungicide applications immediately before harvest or in the packinghouse, however, have been minimally effective or ineffec- tive in preventing symptom development $(1-3,25,30,36)$. Cold storage or storage in the dark delays but does not prevent symptom development $(1,6,16,32)$.

For many years, pathogenic and nonpathogenic isolates of G. citricarpa have been recognized $(7,13,19,21)$. The nonpathogen was distinguished by faster growth, colonies with entire rather than lobed margins, and production of pycnidia and ascomata in culture. The nonpathogen occurs widely on many tropical and subtropical noncultivated and crop plants, including citrus (11), and its geographic distribution on citrus is much wider than that of the pathogenic strain (21). Meyer et al. (24) considered the pathogenic and nonpathogenic strains to be different species. Baayen et al. (4) described the nonpathogenic strain as G. mangiferae A. J. Roy and differentiated it from the pathogenic G. citricarpa based on the above morphological and cultural characteristics and the presence of mucoid sheaths on the conidia of $G$. mangiferae. The two species also were separated based on DNA sequences of the internal transcribed spacer (ITS) region and amplified fragment length polymorphisms.

Diagnosis of black spot is difficult unless typical hard-spot symptoms containing pycnidia of the fungus are present on fruit. The false melanose, virulent, freckle, and cracked spot symptoms can be confused with other diseases and disorders of citrus. Guignardia spp. are not easily isolated from fruit or leaves because the fungus is rather slow-growing and often overgrown by other fungi. No selective medium has been developed for these species. The regulatory protocol for the European Union calls for plating of lesion pieces onto agar and incubation for 14 days for formation of typical colonies of G. citricarpa (5). Lesions that were colonized by $G$. mangiferae have been misdiagnosed initially as black spot using this protocol on fruit in shipments from Florida. However, inoculations of wounded or unwounded fruit with this species did not produce lesions (unpublished). Although G. mangiferae generally is considered an endophyte or saprophyte, in Argentina this species has been associated with a symptom on lemon fruit referred to as "moteado" or speckled blotch (G. Fogliata, personal communication). Thus, once 
isolated, the fungus must be identified as $G$. citricarpa or $G$. mangiferae. The two species can be differentiated by colony morphology and other traits as described above; however, about 10 to 14 days are required for cultures to produce enough growth to be identified (4). Because fruit infections by $G$. citricarpa typically are quiescent for long periods, pathogenicity tests on fruit are difficult and require extended periods. Thus, molecular diagnostic tests are important to be able to identify the species associated with specific types of lesions for etiological studies.

Glienke-Blanco et al. (9) developed a polymerase chain reaction (PCR) technique using specific primers for G. citricarpa with sequences derived from random amplified polymorphic DNA (RAPD) markers. Bonants et al. (5) developed a PCR test using primers from the ITS region to detect $G$. citricarpa directly from fruit lesions. The test was effective in differentiation of $G$. citricarpa from $G$. mangiferae and other common fungi occurring on citrus fruit. However, a fivelesion minimum sample was required to attain a high level of accuracy and the DNA extraction procedure was lengthy. This technique was patented and was available commercially (MGT, Inc., Eugene, OR), but sale of this product has been discontinued. Subsequently, Meyer et al. (23) developed a 1-day PCR method to detect and distinguish $G$. citricarpa and $G$. mangiferae using primers from the ITS region. This method uses a commercially available and relatively expensive kit for rapid DNA extraction from fruit lesions that may not be available in some situations. In many cases, the number of lesions present in fruit shipments is low and lesions are not necessarily identical. Pooling of such lesions for analysis may result in dilution of DNA of the pathogen with that from saprophytes in wounds.

The objectives of this study were to compare the molecular methods available to determine the most effective means of rapid detection and differentiation of $G$. citricarpa and $G$. mangiferae using small amounts of tissue. In addition, new primers and a rapid, less-expensive protocol for detection and differentiation of these two species were developed.

\section{MATERIALS AND METHODS}

Fungal isolates and culture. Thirty isolates of $G$. citricarpa were obtained from small sections from the edge of typical black spot symptoms such as hard spot, virulent spot, and false melanose from fruit of sweet orange (Citrus sinensis) in the state of São Paulo, Brazil. Seven isolates of $G$. mangiferae were recovered in Florida from injuries on fruit peel of sweet orange or grapefruit ( $C$. paradisi) that sometimes resembled hard spot symptoms but had no pycnidia. Another six isolates each of G. citricarpa and G. mangiferae from Brazil were supplied by C. Aguilar (Centro de Citricultura, Cordeiropolis, São Paulo, Brazil). For isolations, fruit pieces were dipped in $70 \%$ ethanol for $30 \mathrm{~s}$, surface disinfested in $1 \% \mathrm{NaOCl}$ for $2 \mathrm{~min}$, rinsed twice in sterilized distilled water, and blotted dry. Tissue pieces were placed on carrot dextrose agar (200 g of macerated carrot, $68.5 \mathrm{~g}$ of dextrose, and $20 \mathrm{~g}$ of agar per 1 liter of distilled water) and incubated at $24^{\circ} \mathrm{C}$ with a 12 -h photoperiod for 10 to 12 days. Isolates were maintained as dry cultures on sterile filter paper in sealed plastic containers with silica gel at $-20^{\circ} \mathrm{C}(27)$.

DNA extraction from fungal isolates. For DNA extraction from fungal cultures, isolates were grown for 7 days in potatodextrose broth (Difco Laboratories, Detroit) on a rotary shaker and mycelia were recovered and ground to a fine powder using liquid nitrogen. Genomic DNA was extracted using the DNeasy Plant Mini Kit (Qiagen, Valencia, CA) following the manufacturer's instructions. In other cases, small amounts of mycelia from the surface of the colonies produced on agar plates were collected with a sterile pipette tip and were used directly as DNA templates.

DNA extraction from fruit lesions. For DNA extraction from single, very small fruit lesions (approximately 2 to $4 \mathrm{~mm}$ in diameter), the diseased tissue was dissected out, removing and discarding as much as possible of the surrounding healthy flavedo, the pigmented outer tissue of the fruit rind. Different methods of tissue disruption, such as grinding with liquid nitrogen or sand, use of an electric rotary tool (Dremel, Racine, WI), or exposure to ultrasound or heat, were tested with the following DNA extraction techniques: (i) the DNeasy Plant Mini Kit according to the manufacturer's instructions, (ii) a Chelex DNA extraction protocol (34) that was modified by centrifugation for $5 \mathrm{~min}$ at $12,000 \times g$ instead of for 10 to $20 \mathrm{~s}$, (iii) a protocol using polyvinylpolypyrrolidone (PVPP) spin columns (Sigma-Aldrich Inc., St. Louis) according to the manufacturer's instructions, (iv) a combination of the Chelex procedure followed by purification with the PVPP spin columns, (v) a procedure using the DNAzol Reagent (Life Technologies, Carlsbad, CA) according to the manufacturer's instructions, (vi) the Ultra Clean Plant DNA isolation and Ultra Clean Soil DNA kits (MO Bio Laboratories Inc., Carlsbad, CA) according to the manufacturer's instructions, (vii) a singlestep protocol for preparation of plant tissue for PCR (33), (viii) an alkaline lysis DNA extraction protocol (15), (ix) the alkaline lysis DNA extraction protocol followed by purification with PVPP spin columns, and (x) the alkaline lysis DNA extraction protocol followed by purification using a dipstick method. With the dipstick method, $150 \mu \mathrm{l}$ of $100 \%$ ethanol and a small piece of cellulose thin-layer chromatography plate (dipstick) were added to the 2-ml tube after alkaline lysis. Tubes were placed on their sides on ice and shaken for 30 min. Liquid was aspirated off and $500 \mu \mathrm{l}$ of wash buffer (10x [Tris, $\mathrm{Na}_{2}$ EDTA, and $\mathrm{NaCl}, \mathrm{pH} 7.0$ ], and $95 \%$ ethanol) diluted to $25 \%$ was added and tubes were inverted to mix the contents. Washing was repeated twice. The dipsticks were placed in a new tube and dried under vacuum. Tubes were placed on their sides and $50 \mu \mathrm{l}$ of TrisEDTA buffer was added. After incubation for $5 \mathrm{~min}$, tubes were spun for $10 \mathrm{~s}$, the dipstick was removed and discarded, and the DNA was recovered.

DNA amplification. Amplifications were carried out in total reaction volume of $20 \mu \mathrm{l}$. PCR mixtures contained $8 \mu \mathrm{l}$ of 2.5× Eppendorf MasterMix (Taq DNA polymerase at $0.06 \mathrm{U} / \mu \mathrm{l}), 2.5 \times \mathrm{Taq}$ reaction buffer (with $125 \mathrm{mM} \mathrm{KCl}, 75 \mathrm{mM}$ Tris-HCl, pH 8.4, $4 \mathrm{mM} \mathrm{Mg}^{2+}$, and $0.25 \%$ Nonidet-P40, $500 \mu \mathrm{M}$ each of dNTP, and stabilizers), $0.8 \mu \mathrm{l}$ of each primer at 10 $\mu \mathrm{M}$, and $2 \mu \mathrm{l}$ of template DNA or mycelia. Amplifications were performed in either a PTC100 or PTC200 thermocycler (MJ Research, Watertown, MA) programmed for $94^{\circ} \mathrm{C}$ for $2 \mathrm{~min}$; followed by 39 cycles at $94^{\circ} \mathrm{C}$ for $30 \mathrm{~s}$, annealing for $30 \mathrm{~s}$, and $72^{\circ} \mathrm{C}$ for $1 \mathrm{~min}$; and a final extension for $10 \mathrm{~min}$ at $72^{\circ} \mathrm{C}$. Annealing temperatures are given in Table 1. PCR products were separated by electrophoresis in $1 \%$ agarose gels in $1 \times$ Tris-borate EDTA buffer.

Comparison of species-specific primers. Seven primer sequences for $G$. citricarpa and five primer sequences for $G$. mangiferae were used (Tables 1 and 2). The specificity and the sensitivity of all primers were evaluated using purified DNA extracts and mycelia from G. citricarpa and G. mangiferae cultures.

Evaluation of species-specific primer pairs using DNA extracted from single black spot fruit lesions. The detection of G. citricarpa using DNA from the different extraction techniques from a single black spot lesion was done initially with primer pairs LM-SA-ITS-Gc and CB-BrRP-Gc, and general primers ITS1 and ITS4 (35). Mycelia from pure fungal cultures were used as positive controls. Fungal mycelia also were mixed with DNA extracted from single black spot lesions to determine the effect of potential inhibitors in the PCR reactions. All experiments were repeated at least once and most many times with consistent results, except as otherwise noted.

Development of new Guignardia sp.specific primers from rDNA ITS sequence data. Primers GCN and GCMR (NP-Br-ITS-Gc) for G. citricarpa and GMN and GCMR (NP-Br-ITS-Gm) for $G$. mangiferae were designed by the authors based on DNA sequences from the ITS region of rDNA deposited in the GenBank 
(accessions AY042911, AY042913, AY042915, AY042917, AY042919, and AY042921). Primers were constructed from the part of the ITS region that showed the greatest differences between $G$. citricarpa and G. mangiferae. Annealing temperatures and formation of secondary structure for the primers were evaluated using the computer program DNA Calculator from Sigma-Genosys. Primers were tested under different annealing temperatures using DNA extracts or using mycelia directly as template DNA.

Sensitivity of Guignardia sp.-specific primers. The detection limits of selected primer sets NP-Br-ITS-Gc, PB-N-ITS-Gc, and LM-SA-ITS-Gc were evaluated by performing PCR using dilutions of known amounts of purified DNA. DNA concentration was determined by UV spectrophotometry. PCR conditions were the same as described above for each primer set. The sensitivity of primers also was evaluated using known amounts of fungal DNA mixed with citrus fruit DNA. For this evaluation, mycelia from pure fungal cultures were added to dilutions of citrus tissue extract ( $1 \mathrm{~g}$ of fruit peel in $9 \mathrm{ml}$ of distilled water) or known amounts of purified fungal DNA was mixed with citrus fruit DNA. The specificity of primer pairs
NP-Br-ITS-Gc, PB-N-ITS-Gc, and LMSA-ITS-Gc also was tested using DNA of some common citrus pathogens, including Alternaria alternata, Colletotrichum acutatum, C. gloeosporioides, Diaporthe citri, Mycosphaerella citri, and Penicillium digitatum. All experiments were repeated at least once and most many times with consistent results, except where otherwise noted.

Evaluation of primers for detection of Guignardia spp. from black spot-like symptoms in Florida. The NP-Br-ITS-Gc and NP-Br-ITS-Gm primer pairs were evaluated for detection of Guignardia spp. in Florida. Necrotic lesions on grapefruit and orange fruit collected from groves near Lake Alfred, FL were dissected and half of each lesion was used for isolations on culture media and the other half for PCR. In addition, decaying leaves collected from grapefruit groves near Lake Alfred with fungal structures fitting the description of $G$. mangiferae were used to evaluate the detection of this species with primer pair NP-Br-ITS-Gm. Leaves without those fungal structures were used for comparisons. All experiments were repeated at least once and most many times with consistent results, except where otherwise noted.

\section{RESULTS}

Evaluation of species-specific primers using purified DNA from fungal isolates or mycelium. Primer pairs listed in Tables 1 and 2 were evaluated for their ability to detect and differentiate G. citricarpa and $G$. mangiferae using purified DNA extracted from cultures of these species. All pairs produced amplicons specifically of G. citricarpa or G. mangiferae with the respective primer pairs (Table 3 ). However, primer pairs GC-OR-ETS-1-Gc, GC-ORETS-2-Gc, GC-OR-ETS1-Gm, GC-ORETS2-Gm, and GC-OR-CS-Gm were not as consistent as some of the other primer pairs.

All primer pairs were also effective in specifically detecting $G$. citricarpa and $G$. mangiferae using mycelium directly in PCR. However, primer pairs GC-OR-ITSGc, CB-Br-RP-Gc, LM-SA-ITS-Gc, PB$\mathrm{N}-\mathrm{ITS}-\mathrm{Gc}$, and NP-Br-ITS-Gc were more consistent in showing an intense amplicon of expected size (Table 3 ).

For example, primer pair LM-SA-ITSGc, developed in South Africa, produced specific bands with mycelia of 20 different isolates of $G$. citricarpa from Brazil, but did not produce bands with the 12 different isolates of G. mangiferae (Fig. 1A). With specific primers for $G$. mangiferae, primer

Table 1. Primer pairs used in polymerase chain reaction (PCR) to detect and identify Guignardia citricarpa

\begin{tabular}{|c|c|c|c|c|c|}
\hline Designation & $\begin{array}{c}\text { Primer pair } \\
\text { (reference) }\end{array}$ & Primer sequence & Origin $^{a}$ & $\begin{array}{c}\text { Annealing } \\
\text { temperature }\left({ }^{\circ} \mathbf{C}\right)\end{array}$ & $\begin{array}{l}\text { PCR product } \\
\text { size (bp) }\end{array}$ \\
\hline \multirow[t]{2}{*}{ GC-OR-ITS-Gc } & ITS 1F & TAAAAAAGCCGCCCGACCTAC & ITS & 55 & 300 \\
\hline & $5.8 \mathrm{~S} 2 \mathrm{R}$ & TGCAATTCACATTACTTATCGC & & & \\
\hline \multirow[t]{2}{*}{ GC-OR-ETS1-Gc } & FRAG $1-4 \mathrm{~F}$ & TCAGACACTCGGGGGTAAG & ETS & 53 & 280 \\
\hline & $1468 \mathrm{VI}-1 \mathrm{R}$ & TGCTGGCACTCGTGAGAG & $\ldots$ & & \\
\hline \multirow[t]{2}{*}{ GC-OR-ETS2-Gc } & $1468 \mathrm{VI}-1 \mathrm{~F}$ & TCTCACGAGTGCCAGCAG & ETS & 53 & 380 \\
\hline & SSU 9R & CTAGAATTACCACGGTTATCC & & & \\
\hline \multirow[t]{2}{*}{ GC-OR-CS-Gc } & CIT 2-1 CHS-2F & TATGTCTCCCCTTTCCTCG & Chitin synthase & 53 & 180 \\
\hline & CHS 4R & TGATTCTTTTCCTTCAAGCAG & & & \\
\hline \multirow[t]{2}{*}{ CB-Br-RP-Gc } & GCP1 (9) & AAGTGTGAGTGTCGAAGGTGG & RAPD & 67 & 370 \\
\hline & GCP2 (9) & GACGACTCGCTTTTCTACGGC & & & \\
\hline \multirow[t]{2}{*}{ LM-SA-ITS-Gc } & CITRI1 (23) & GAAAGGTGATGGAAGGGAG & ITS & 55 & 580 \\
\hline & ITS4 (35) & TCCTCCGCTTATTGATATGC & & & \\
\hline \multirow{2}{*}{ PB-N-ITS-Gc } & GCF3 (5) & AAAAAGCCGCCCGACCTACCT & ITS & 65 & 490 \\
\hline & GCR7 (5) & TGTCCGGCGGCCAG & & & \\
\hline \multirow[t]{2}{*}{ NP-Br-ITS-Gc } & GCN & CTGAAAGGTGATGGAAGGGAGG & ITS & 64 & 300 \\
\hline & GCMR & CATTACTTATCGCATTTCGCTGC & $\ldots$ & $\ldots$ & $\ldots$ \\
\hline
\end{tabular}

${ }^{\mathrm{a}}$ ITS = internal transcribed spacer, ETS = external transcribed spacer, and RAPD = random amplified polymorphic DNA.

Table 2. Primer pairs used in polymerase chain reaction (PCR) to detect and identify Guignardia mangiferae

\begin{tabular}{|c|c|c|c|c|c|}
\hline Designation & $\begin{array}{l}\text { Primer pair } \\
\text { (reference) }\end{array}$ & Primer sequence & Origin $^{a}$ & $\begin{array}{c}\text { Annealing } \\
\text { temperature }\left({ }^{\circ} \mathrm{C}\right)\end{array}$ & $\begin{array}{l}\text { PCR product } \\
\text { size (bp) }\end{array}$ \\
\hline \multirow[t]{2}{*}{ GC-OR-ETS1-Gm } & CITR 3-1 VI-1F & CTCGCAAAGTAACCCCTTC & ETS & 53 & 300 \\
\hline & SSU 11R & TCTAATAAATACACСССТТСС & & & \\
\hline \multirow[t]{2}{*}{ GC-OR-ETS2-Gm } & CITR 3-1 VI-3F & TAАСТАСТСТGСССССТСАС & ETS & 53 & 320 \\
\hline & SSU 11R & TCТАAТАAАТАСАССССТТСС & & & \\
\hline \multirow[t]{2}{*}{ GC-OR-CS-Gm } & CHS $1 \mathrm{~F}$ & CAGTTTGAAGCCTTTTCGGG & Chitin synthase & 53 & 180 \\
\hline & CHS 1R & AGAGTTGATTTTCTTTTGATTC & & & \\
\hline \multirow[t]{2}{*}{ LM-SA-ITS-Gm } & CAMEL2 (23) & AGTATACAAAACTCAAGAATTC & ITS & 55 & 430 \\
\hline & ITS4 (35) & TCCTCCGCTTATTGATATGC & & & \\
\hline \multirow[t]{2}{*}{ PB-N-ITS-Gm } & GCF2 (5) & TAACTTCTATTGAAAGGTTCCAGAGT & ITS & 65 & 210 \\
\hline & GCR4 (5) & TCAGGACTTCACAAAATGAATTCTT & & & \\
\hline \multirow[t]{2}{*}{ NP-Br-ITS-Gm } & GMN & CGCTACAACGCCGAAATGA & ITS & 64 & 290 \\
\hline & GCMR & CATTACTTATCGCATTTCGCTGC & $\ldots$ & $\ldots$ & $\ldots$ \\
\hline
\end{tabular}

${ }^{a}$ ETS and ITS = external and internal transcribed spacer, respectively. 
pair GC-OR-ETS2-Gm produced bands of the expected size with all 13 different isolates of G. mangiferae, but did not yield any products with 26 isolates of $G$. citricarpa (Fig. 1B). Primer pair LM-SA-ITS-Gm did not amplify any products with mycelia of 20 different isolates of G. citricarpa, but amplified specific products with all 11 isolates of G. mangiferae tested (Fig. 1C).

Evaluation of species-specific primers using DNA extracted from single black spot lesions. The 10 DNA extraction procedures described in Materials and Methods were evaluated by performing PCR using DNA from single fruit lesions to determine the most effective extraction procedures. However, G. citricarpa was not detected using the primer pair LM-SAITS-Gc with any of the extraction procedures tested and bands were produced only with the positive controls where mycelia from fungal colonies were used as DNA templates (Table 3 ). When positive samples were added to the DNA extracted from single fruit lesions, products were amplified effectively and, thus, there was no evidence for the presence of inhibitors. Primer pairs GC-OR-ITS-Gc, GC-ORETS2-Gc, GC-OR-CS-Gc, and LM-SAITS-Gc all amplified products with mycelia, but only primer pair GC-OR-ITS-Gc proved to be more sensitive than the others when purified DNA from a single fruit lesion was used (Fig. 2). In general, products were amplified much more effectively when using mycelia rather than DNA from single fruit lesions (Table 3 ).

Evaluation of new primers developed from ITS sequence data. Because existing primer pairs showed low sensitivity for detecting Guignardia spp. when using DNA extracted from single fruit lesions using a quick extraction method, the new primer pairs NP-Br-ITS-Gc and NP-BrITS-Gm (Tables 1 and 2) were designed from the ITS region using data available in
GenBank. Primer pair NP-Br-ITS-Gc was compared with the previously published primer pairs $(5,23)$, designated herein as PB-N-ITS-Gc and LM-SA-ITS-Gc, respectively, for sensitivity in detection of $G$. citricarpa using purified DNA extracted from fungal cultures, mycelia, and DNA from single fruit lesions as source materials. For the latter samples, the alkaline hydrolysis procedure followed by the dipstick method was chosen. When DNA from pure fungal cultures was used, tem-
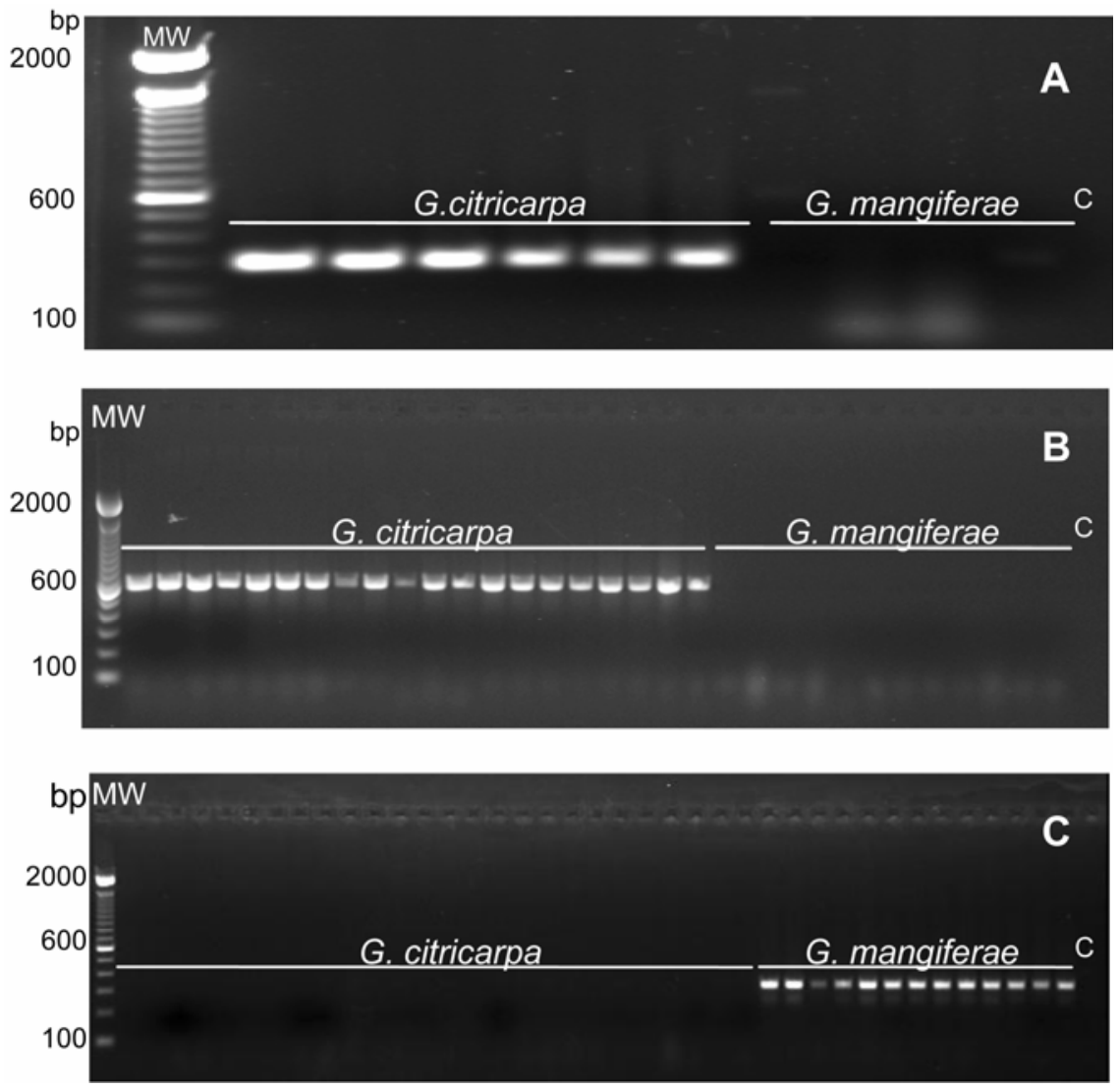

Fig. 1. Detection and identification of Guignardia citricarpa using DNA extracts from fungal cultures or mycelia directly for polymerase chain reaction. A, Primer pair CB-Br-RP-Gc: lanes 2-7, DNA extracts of different isolates of G. citricarpa; lanes 8-11, DNA extracts of different isolates of $G$. mangiferae; lane 12, no DNA control. B, Primer pair LM-SA-ITS-Gc: lanes 2-21, mycelia of different isolates of G. citricarpa; lanes 22-33, mycelia of different isolates of G. mangiferae; lane 33, no DNA control. C, Primer pair GC-OR-ETS2-Gm: lanes 2-26, mycelia of different isolates of G. citricarpa; lanes 27-39, mycelia of different isolates of G. mangiferae; lane 40, no DNA. The molecular weight (MW) standard is a 100-bp DNA ladder.

Table 3. Comparison of species-specific primers for Guignardia citricarpa and G. mangiferae to detect and identify each fungus using DNA extracts from fungal cultures, mycelia directly, or extracts from single black spot lesions as templates in polymerase chain reaction (PCR) reactions

\begin{tabular}{|c|c|c|c|c|c|c|}
\hline \multirow[b]{2}{*}{ Species $^{b}$} & \multirow[b]{2}{*}{ Primer pair } & \multicolumn{2}{|c|}{$\begin{array}{l}\text { Identification in DNA extracts } \\
\text { from fungal cultures }\end{array}$} & \multicolumn{2}{|c|}{$\begin{array}{l}\text { Detection using mycelia } \\
\text { directly in PCR }\end{array}$} & \multirow{2}{*}{$\frac{\text { Detection from lesion }^{\mathrm{a}}}{\text { G. } \text { citricarpa }^{2}}$} \\
\hline & & G. citricarpa & G. mangiferae & G. citricarpa & G. mangiferae & \\
\hline G. citricarpa & GC-OR-ITS-Gc & $++^{c}$ & - & ++ & - & \pm \\
\hline G. citricarpa & GC-OR-ETS1-Gc & \pm & - & + & - & - \\
\hline G. citricarpa & GC-OR-ETS2-Gc & \pm & - & + & - & - \\
\hline G. citricarpa & GC-OR-CS-Gc & ++ & - & + & - & - \\
\hline G. citricarpa & CB-Br-RP-Gc & ++ & - & ++ & - & - \\
\hline G. citricarpa & LM-SA-ITS-Gc & ++ & - & ++ & - & - \\
\hline G. citricarpa & PB-N-ITS-Gc & ++ & - & ++ & - & - \\
\hline G. citricarpa & NP-Br-ITS-Gc & ++ & - & ++ & - & + \\
\hline G. mangiferae & GC-OR-ETS1-Gm & - & \pm & - & + & $\mathrm{n} / \mathrm{t}$ \\
\hline G. mangiferae & GC-OR-ETS2-Gm & - & \pm & - & + & $\mathrm{n} / \mathrm{t}$ \\
\hline G. mangiferae & GC-OR-CS-Gm & - & \pm & - & + & $\mathrm{n} / \mathrm{t}$ \\
\hline G. mangiferae & LM-SA-ITS-Gm & - & + & - & + & $\mathrm{n} / \mathrm{t}$ \\
\hline G. mangiferae & PB-N-ITS-Gm & - & + & - & + & $\mathrm{n} / \mathrm{t}$ \\
\hline G. mangiferae & NP-Br-ITS-Gm & - & + & - & + & $\mathrm{n} / \mathrm{t}$ \\
\hline
\end{tabular}

\footnotetext{
${ }^{\text {a }}$ Detection in extract from a single black spot lesion.

${ }^{\mathrm{b}}$ Specificity of designed primer pair.

c Symbols: $++=$ intense amplicon of expected size produced, $+=$ amplicon of expected size produced, $-=$ no amplicon produced, $\pm=$ inconsistent reactions, and $\mathrm{n} / \mathrm{t}=$ not tested.
} 
plate thresholds for the detection of $G$. citricarpa were concentrations of 0.001 $\mathrm{ng} / \mu \mathrm{l}$ for NP-Br-ITS-Gc, $0.01 \mathrm{ng} / \mu \mathrm{l}$ for PB-N-ITS-Gc, and $0.1 \mathrm{ng} / \mu \mathrm{l}$ for LM-SAITS-Gc (Fig. 3). When primer pairs LMSA-ITS-Gc were tested using an annealing temperature of $64^{\circ} \mathrm{C}$ instead of the recommended $56^{\circ} \mathrm{C}$ (23), detection of G. citricarpa was achieved with a template concentration of $0.001 \mathrm{ng} / \mu \mathrm{l}$ (data not shown).

The NP-Br-ITS-Gc primer pair was evaluated for the ability to detect $G$. citricarpa using DNA from single fruit lesions from different symptoms on fruit. In this case, the alkaline hydrolysis procedure followed by the dipstick method also was fied products of expected size from hard spot, virulent spot, and cracked spot lesions. In the example in Figure 4, specific from 15 of 16 lesions. When fruit extracts or fruit DNA were added to purified DNA of $G$. citricarpa, no inhibitory effects on the level of detection of G. citricarpa were found (Fig. 5). Primer pair NP-Br-ITS-Gc was specific for $G$. citricarpa and did not produce products using DNA or mycelia from other citrus pathogens such as $A$. alternata, $C$. acutatum, C. gloeosporioides, D. citri, M. citri, or P. digitatum (data not shown).

Evaluation of primers for detection of Guignardia spp. from black-spot-like symptoms in Florida. When the NP-BrITS-Gc and NP-Br-ITS-Gm primer pairs were evaluated for detection of Guignardia spp. on fruit lesions in Florida, neither primer pair detected the presence of these fungi. However, Guignardia spp. were not isolated from the other half of the lesions either. Addition of DNA from G. mangiferae to DNA from negative samples from fruit lesions showed that inhibitors probably did not play a role in the failure to detect Guignardia spp. from fruit lesions in Florida (Fig. 5). When the NP-Br-ITS$\mathrm{Gc}$ and NP-Br-ITS-Gm primer pairs were evaluated for detection of Guignardia spp. on decaying leaves bearing fungal strucused. This primer pair consistently ampliproducts for $G$. citricarpa were amplified

tures, primer pair NP-Br-ITS-Gm was able to detect $G$. mangiferae from one of nine leaf samples (data not shown).

\section{DISCUSSION}

Molecular procedures for detection and differentiation of $G$. citricarpa and $G$. mangiferae have been developed and improved in recent years $(5,9,23,24)$. Species-specific primers were developed for Guignardia spp. from the ITS region $(5,23,24)$ and from RAPD bands $(9)$. Bonants et al. (5) developed a PCR detection method using primers from the ITS region which was highly effective and specific for detecting G. citricarpa. However, the DNA extraction procedure required was lengthy and a five-lesion sample was required for extraction. Meyer et al. (23) were able to successfully detect and differentiate the two species using different primers from the ITS region and a rapid DNA extraction technique. In our studies, we were not able to detect $G$. citricarpa from one single black spot lesion when using their protocol. In addition, the DNA extraction procedure used a commercial kit that may not be available or affordable in some areas. However, that procedure (23) proved to be more effective when the annealing temperature was increased.

The original purpose of our study was to compare the various primers and procedures available and to evaluate their effectiveness. Nearly all of the primer sets developed previously from RAPD bands (9) and from the ITS region $(5,23,24)$, as well as previously unpublished primer sequences from the external transcribed spacer and chitin synthase regions, were effective for detecting and differentiating the two species when purified DNA extracted from fungal cultures or mycelia were used as DNA templates. Thus, it appeared that any of the primer sets would be useful for identification of these species in culture and for detection in fruit if sufficient tissue were available.

Because Guignardia spp. are slowgrowing fungi and sometimes difficult to

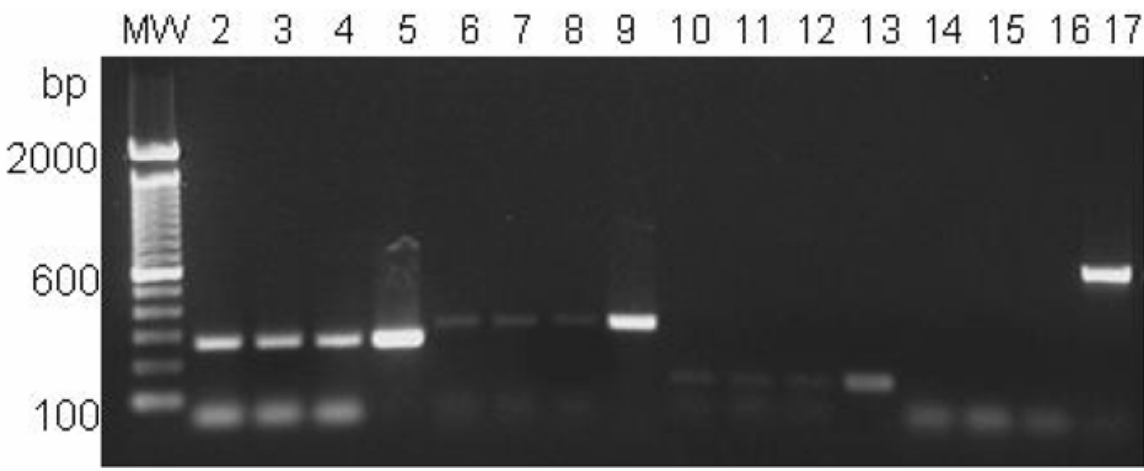

Fig. 2. Sensitivity of selected primer pairs (as indicated) for detection of Guignardia citricarpa using DNA from symptomatic orange peel lesions that was isolated by a quick extraction protocol adapted from Klimyuk et al. (15). The fourth lane in each set is a positive control using mycelia from isolate BS-CCSM-1; whereas, in the first three lanes in each set, DNA extracts from fruit tissue were used as DNA templates. The molecular weight (MW) standard is a 100-bp DNA ladder. isolate, a rapid detection direct from fruit lesions would be ideal. However, problems were encountered in the detection using DNA from a single fruit lesion. Thus, primer sets LM-SA-ITS-Gc and CB-BrRP-Gc were selected to evaluate a number of DNA extraction procedures. This choice was unfortunate because it subsequently was found that other primer sets, such as GC-OR-ITS-Gc, proved more sensitive for detection from fruit lesions using quick DNA extraction protocols (Fig. 3). The main difficulty encountered for DNA extraction from single lesions from fruit tissue was that the small size of the tissue piece made it very difficult to grind or macerate. Thus, the alkaline lysis protocol

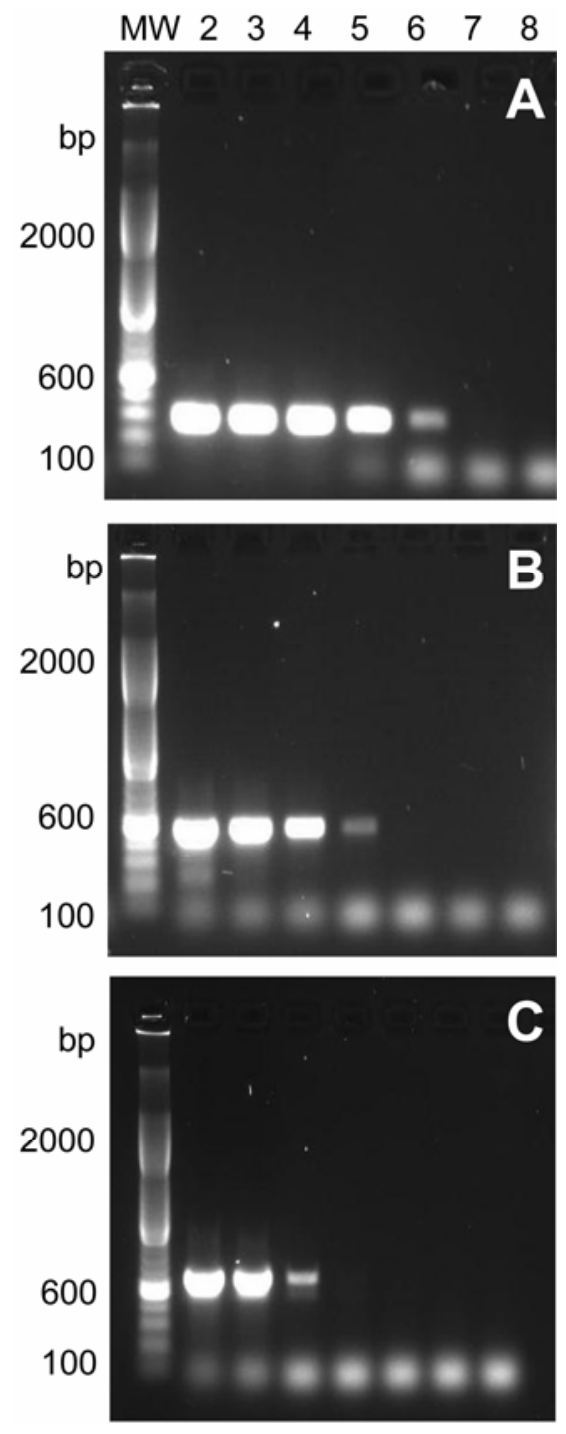

Fig. 3. Comparison of the sensitivity of primers designed in this study with other previously published primers. DNA was extracted from cultures of Guignardia citricarpa and polymerase chain reaction were carried out with $\mathbf{A}$, primer pairs NP-Br-ITS-Gc; $\mathbf{B}$, primer pairs PBN-ITS-Gc; and C, primer pairs LM-SA-ITS-Gc. Lane 2, $5 \mathrm{ng} / \mu \mathrm{l}$; lane 3, $1 \mathrm{ng} / \mu \mathrm{l}$; lane 4, 0.1 $\mathrm{ng} / \mu \mathrm{l}$; lane $5,0.01 \mathrm{ng} / \mu \mathrm{l}$; lane $6,1 \mathrm{pg} / \mu \mathrm{l}$; lane 7 , $0.1 \mathrm{pg} / \mu \mathrm{l}$; lane 8 , no DNA control. The molecular weight (MW) standard is a 100-bp DNA ladder. 
bp MW $2 \begin{array}{lllllllllllllllll} & 3 & 4 & 5 & 6 & 7 & 8 & 9 & 10 & 11 & 12 & 13 & 14 & 15 & 16 & 17 & 18\end{array}$

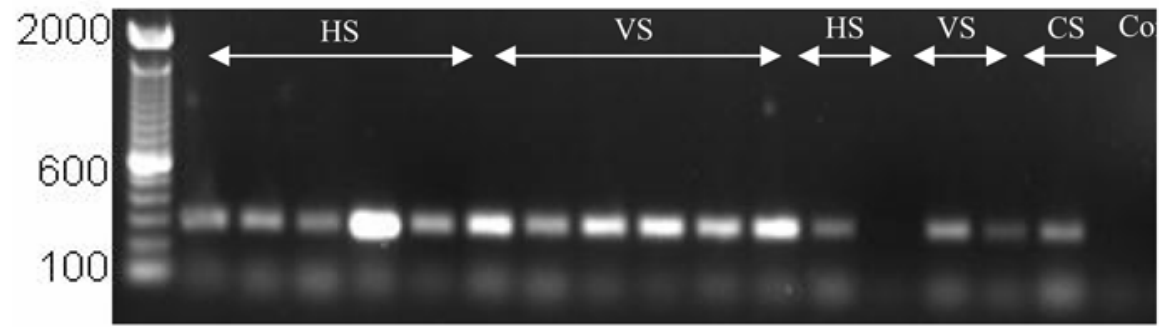

Fig. 4. Detection of Guignardia citricarpa in single hard spot (HS), virulent spot (VS), or cracked spot (CS) fruit lesions using primer pair NP-Br-ITS-Gc. The last lane is a no-DNA control. The molecular weight (MW) standard is a 100-bp DNA ladder.

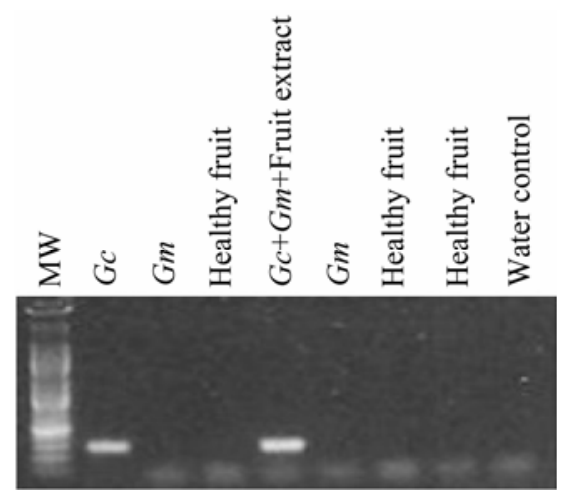

Fig. 5. Effect of flavedo extracts on polymerase chain reaction detection of DNA of Guignardia citricarpa $(G c)$ and $G$. mangiferae $(G m)$ using primer pair NP-Br-ITS-Gc. G. citricarpa was detected in the $G c+G m+$ fruit extract mixture. Controls consisted of water or extracts from healthy fruit. The molecular weight (MW) standard is a 100-bp DNA ladder.

followed by the dipstick, where boiling was used to break down the tissue, was chosen and proved to be very effective.

Subsequently, we developed another primer set from the ITS region that proved to be highly effective for the detection of G. citricarpa from single fruit lesions using the alkaline lysis rapid DNA extraction procedure. This primer set NP-Br-ITS-Gc was able to detect $G$. citricarpa in various types of black spot lesions and was very sensitive, and flavedo extracts did not interfere with the detection. In limited tests, the G. mangiferae primer set NP-Br-ITS$\mathrm{Gm}$ was able to detect this fungus in decaying citrus leaves in Florida. However, we detected $G$. mangiferae in only one of the nine samples; thus, it appears that the fungal structures observed on the other leaves were of an unrelated fungal species. It did not detect $G$. mangiferae in fruit lesions, but neither were Guignardia spp. isolated from any of these lesions.

We have developed a highly specific, rapid, and inexpensive assay for the detection and differentiation of $G$. citricarpa and $G$. mangiferae. Most of the other primer sets evaluated were species specific and useful for detection. However, in our work, they often were less sensitive than the new primers when quick DNA extraction protocols from single fruit lesions were used. Several molecular systems are now available and can be used for detecthe etiology of this disease on citrus.

\section{LITERATURE CITED} Adaskaveg, J. E., and Timmer, L. W. 2006. Effect of fungicides and storage conditions on postharvest development of citrus black spot and survival of Guignardia citricarpa in fruit tissues. Plant Dis. 90:1419-1424.

2. Andrade, A. G., Bellotte, J.A.M., Barbosa, C.R.C., Correa, E. B., Baldassari, R. B., and Goes, A. 2001. Efeito de eletrochoque combinado com thiabendazole e $\mathrm{KCl}$ e temperatura de armazenamento no controle de Guignardia citricarpa em frutos cítricos na fase de póscolheita. Fitopatol. Bras. 26(Suppl.):396.

3. Andrade, A. G., Bellotte, J.A.M., Barbosa, C.R.C., Correa, E. B., Baldassari, R. B., and Goes, A. de. 2001. Efeito de choque térmico combinado com thiabendazole e glicerol no controle de Guignardia citricarpa em frutos cítricos na fase pós-colheita. Fitopatol. Bras. 26(Suppl.):396-397.

4. Baayen, R. P., Bonants, P.J.M., Verkley, G., Carroll, G. C., van de Aa, H. A., de Weerdt, M., van Brouwershaven, I. R., Schutte, G. C., Maccheroni, Jr., W., Glienke de Blanco, C., and Azevedo, J. L. 2002. Non-pathogenic isolates of the citrus black spot fungus, Guignardia citricarpa, identified as a cosmopolitan endophyte of woody plants, G. mangiferae (Phyllosticta capitalensis). Phytopathology

5. Bonants, P. J. M., Carroll, G. C., DeWeerdt, M., Van Brouwershaven, I. R., and Baayen, R. PCR-based detection method for pathogenic isolates of the citrus black spot fungus, Guignardia citricarpa. Eur. J. Plant Pathol. 109:503-513.

6. Brodrick, H. T. 1975. Light and temperature effects on symptom development of citrus black spot disease. Citrus Series H. 1.1.1(a). Farming in South Africa. Dep. Agric. Tech. Serv., Pretoria, South Africa.

7. Chiu, R. J. 1955. Studies on black spot of citrus. J. Agric. For. 9:1-8.

8. Garrán, S. M. 1996. Citrus black spot in the northeast of Entre Rios: etiology, epidemiology and control. Proc. Int. Soc. Citricult. 1:466-470.

9. Glienke-Blanco, C., Aguilar-Vildoso, C. I., Vieira, M. L. C., Barroso, P. A. V., and Azevedo, J. L. 2002. Genetic variability in the endophytic fungus Guignardia citricarpa isolated from citrus plants. Genet. Mol. Biol. 25:251-255.

10. Goes, A. de, Baldassari, R. B., Feichtenberger, E., Sposito, M. B., and Vildosa, C. I. A. 2000. Cracked spot, a new symptom of citrus black spot (Guignardia citricarpa) in Brazil. (Abstr.) Proc. Int. Soc. Citricult. 1:145. tion on commercial fruit and in studies of

1. Agostini, J. P., Peres, N. A., Mackenzie, S. J., 92:464-477. P. 2003. Development and validation of a fast
11. Holliday, P. 1980. Fungus Diseases of Tropical Crops. Cambridge University Press, Cambridge.

12. Huang, C. S., and Chang, S. L. 1972. Leaf infection with citrus black spot and perithecial development in relation to ascospore discharge of Guignardia citricarpa Kiely. J. Taiwan Agric. Res. 21:256-263.

13. Kiely, T. B. 1948. Preliminary studies on Guignardia citricarpa n. sp., the ascigerous stage of Phoma citricarpa McAlp., and its relation to blackspot of citrus. Proc. Linn. Soc. N. S. W. 73:249-292.

14. Kiely, T. B. 1950. Control and epiphytology of black spot of citrus. N. S. W. Dep. Agric. Sci. Bull. 71:1-66.

15. Klimyuk, V. I., Carroll, B. J., Thomas, C. M., and Jones, J. D. G. 1993. Alkali treatment for rapid preparation of plant material for reliable PCR analysis: technical advance. Plant J. 3:493-494.

16. Korf, H. J. G., Schutte, G. C., and Kotzé, J. M. 2001. Effect of packinghouse procedures of the viability of Phyllosticta citricarpa, anamorph of the black spot pathogen. Afr. Plant Prot. 7:103-109.

17. Kotzé, J. M. 1981. Epidemiology and control of citrus black spot in South Africa. Plant Dis. 65:945-950.

18. Kotzé, J. M. 2000. Black spot. Pages 23-25 in: Compendium of Citrus Diseases. L. W. Timmer, S. M. Garnsey, and J. H. Graham, eds. American Phytopathological Society Press, Inc., St. Paul, MN.

19. Lee, Y. S. 1969. Pathogenicity of different isolates of Guignardia citricarpa Kiely from various sources of Ponkan fruits. J. Taiwan Agric. Res. 18:45-50.

20. Lee, Y. S., and Huang, C. S. 1973. Effect of climatic factors on the development and discharge of ascospores of the citrus black spot fungus. J. Taiwan Agric. Res. 22:135-144.

21. McOnie, K. C. 1964. Source of inoculum of Guignardia citricarpa, the citrus black spot pathogen. Phytopathology 54:64-67.

22. McOnie, K. C. 1967. Germination and infection of citrus by ascospores of Guignardia citricarpa in relation to control of black spot. Phytopathology 57:743-746.

23. Meyer, L., Sanders, G. M., Jacobs, R., and Korsten, L. 2006. A one-day sensitive method to detect and distinguish between the citrus black spot pathogen Guignardia citricarpa and the endophyte Guignardia mangiferae. Plant Dis. 90:97-101.

24. Meyer, L. Slippers, B., Korsten, L. Kotzé, J. M., and Wingfield, M. J. 2001. Two distinct Guignardia species associated with citrus in South Africa. S. Afr. J. Sci. 97:191-194.

25. Nam, K. W., Kweon, H. M., and Song, N. H. 1993. Storage of Satsuma mandarin. I. Storability of Satsuma mandarin influenced by thiophanate-methyl treatment and mechanical injuries. J. Korean Soc. Hortic. Sci. 34:279284.

26. Paul, I., van Jaarsveld, A.S., Korsten, L., and Hattingh, V. 2005. The potential global distribution of citrus black spot caused by Guignardia citricarpa Kiely: likelihood of disease establishment in the European Union. Crop Prot. 24:297-308

27. Peever, T. L., Canihos, Y., Olsen, L., Ibáñez, A., Liu, Y.-C., and Timmer, L. W. 1999. Population genetic structure and host specificity of Alternaria spp. causing brown spot of Minneola tangelo and rough lemon in Florida. Phytopathology 89:851-860.

28. Peres, N. A. R., and Timmer, L. W. 2003 Citrus black spot caused by Guignardia citricarpa. CABI Crop Protection Compendium. CAB International, Oxford.

29. Reis, R. F., Timmer, L. W., and de Goes, A. 2005. Effect of temperature, leaf wetness, and rainfall on the production of ascospores of 
Guignardia citricarpa and on black spot severity. Fitopatol. Bras. 30:630-639.

30. Seberry, J. A., Leggo, D., and Kiely, T. B. 1967. Effect of skin coatings on the development of black spot in stored Valencia oranges. Aust. J. Exp. Agric. Anim. Husb. 7:593-600.

31. Timmer, L. W. 1999. Diseases of fruit and foliage. Pages 107-115 in: Citrus Health Management. L. W. Timmer and L. W. Duncan, eds. American Phytopathological Society Press, Inc., St. Paul, MN.
32. Timossi, A. J., de Goes, A., Kupper, K. C., Baldassari, R. B., and dos Reis, R. F. 2003. Influência da temperatura e da luminosidade no desenvolvimento de Guignardia citricarpa, agente causal da mancha preta dos frutos citricos. Fitopatol. Bras. 28:489-494.

33. Thomson, D., and Henry, R. 1995. Single-step protocol for preparation of plant tissue for analysis by PCR. Biotechniques 19:394-398.

34. Walsh, P. S., Metzger, D. M., and Higuchi, R. 1991. Chelex 100 as a medium for simple ex- traction of DNA for PCR-based typing from forensic material. Biotechniques 10:506-513.

35. White, T. J., Bruns, T., Lee, S., and Taylor, J. 1990. Amplification and direct sequencing of fungal rDNA genes for phylogenetics. Pages 315-322 in: PCR Protocols: A Guide to Methods and Applications. M. A. Innis, D. H. Gelfand, J. J. Sninsky, and T. J. White, eds. Academic Press, San Diego, CA.

36. Wild, B. L. 1981. The effects of waxing citrus fruit. Rural Newsl. 79:14-19. 